\title{
Flow cytometric sorting, phylogenetic analysis and in situ detection of Oscillospira guillermondii, a large, morphologically conspicuous but uncultured ruminal bacterium
}

\author{
Kazuhiro Yanagita, ${ }^{1,2}$ Akira Manome, ${ }^{1,2}$ Xian-Ying Meng, ${ }^{1}$ \\ Satoshi Hanada, ${ }^{1}$ Takahiro Kanagawa, ${ }^{1}$ Takayasu Tsuchida, ${ }^{1,2}$ \\ Roderick I. Mackie ${ }^{3}$ and Yoichi Kamagata ${ }^{1}$ \\ ${ }^{1}$ Institute for Biological Resources and Functions, National Institute of Advanced Industrial \\ Science and Technology (AIST), Central 6, Higashi 1-1-1, Tsukuba, Ibaraki 305-8566, Japan \\ ${ }^{2}$ Center Research Laboratories, Ajinomoto Co., Kawasaki 210-8681, Japan \\ ${ }^{3}$ Department of Animal Sciences, University of Illinois Urbana-Champaign, Urbana IL 61801, \\ USA
}

Correspondence Yoichi Kamagata y.kamagata@aist.go.jp

\begin{abstract}
Flow cytometric sorting based on its large cell size enabled an enriched fraction of Oscillospira guillermondii cells to be obtained from the rumen contents of a sheep. Phylogenetic analysis based on cloned 16S rDNA sequences indicated that the bacterium is a member of the low-G $+\mathrm{C}$ Gram-positive bacterial cluster. Sporobacter termitidis and Papillibacter cinnamivorans were the most closely related known species, with sequence similarities of only $86 \cdot 3-88 \cdot 1 \%$. Fluorescently labelled 16S rRNA-targeted oligonucleotide probes specific for Oscillospira were designed and applied to the rumen sample from which the enriched fraction was obtained. The probes hybridized specifically with the large, morphologically conspicuous Oscillospira cells.
\end{abstract}

Oscillospira guillermondii is a large bacterium $(3-6 \times$ $10-40 \mu \mathrm{m})$, often observed in the rumen contents of sheep and cattle as well as the alimentary tract of other herbivorous animals. Oscillospira is characterized as a Grampositive bacterium, with closely spaced transverse septa and endospores (Gibson, 1974, 1986; Grain \& Senaud, 1976; Stewart et al., 1997). Although this bacterium was first described almost a century ago (Chatton \& Pérard, 1913), growth in pure culture has not been reported (Gibson, 1974, 1986; Stewart et al., 1997), hence, little is known of its ecological role and physiological properties in the intestinal tract. Clarke (1979) found that Oscillospira and other large bacteria attached rapidly to the cuticular surface of clover and grass leaves in the rumen, suggesting that the cuticle of green leaves constitutes a specific niche for these bacteria. Warner (1966) investigated the relationship between grazing behaviour and changes in rumen microbial populations in sheep and found that the population of Oscillospira in the rumen fluctuated and the length of the trichome also

Published online ahead of print on 9 May 2003 as DOI 10.1099/ ijs.0.02541-0.

Abbreviations: FCM, flow cytometry; FISH, fluorescent in situ hybridization.

The GenBank/EMBL/DDBJ accession numbers for the O. guillermondii $16 S$ rDNA sequences OSC1-OSC5 are AB040495-AB040499. changed depending upon the amount of feed consumed. Kurihara et al. (1968) reported that total counts of Oscillospira in the sheep rumen tended to decrease in the presence of ciliates. Although the number of Oscillospira cells is relatively small compared with other bacterial cells, they may make a significant contribution to rumen fermentation because of their large biomass, roughly equivalent to that of ruminal ciliate protozoa (Clarke, 1979; Williams \& Coleman, 1997).

To date, culture-based techniques have not enabled the phylogenetic relatedness of Oscillospira to known bacteria to be studied. Flow cytometry (FCM), a well-established technology in cell biology and medical microbiology, is now being applied to microbial ecology studies. FCM allows the rapid analysis of bacterial communities and enables single cells to be detected, quantified and sorted according to differences in size, DNA content or phylogenetic affiliation as assessed by fluorescently labelled rRNA-targeted oligonucleotide probes (Amann et al., 1990; Button et al., 1996; Davey \& Kell, 1996; Jansson \& Prosser, 1997; Wallner et al., 1997). Very recently, Zoetendal et al. (2002) have detected and enumerated uncultured Ruminococcus obeum-like bacteria in human faecal samples by fluorescent in situ hybridization (FISH) and FCM using 16S rRNA-targeted probes. In this study, Oscillospira cells were sorted by FCM based on cell size and the 16S rDNA was amplified and 
sequenced. 16S rRNA-targeted oligonucleotide probes were designed to detect specifically this large, morphologically conspicuous but uncultured ruminal bacterium.

Rumen contents were obtained from a Corriedale sheep weighing approximately $50 \mathrm{~kg}$. The sheep was fed twice daily at 9:00 am and 4:00 pm with $600 \mathrm{~g}$ timothy hay. In addition, the sheep received $150 \mathrm{~g}$ concentrate feed (Chikushi 5P) at 9:00 am. Rumen contents were collected through a ruminal cannula at $2: 00 \mathrm{pm}$. The contents were centrifuged $(200 \mathrm{~g}, 5 \mathrm{~min})$ to remove large particles, consisting mainly of undigested fibres, and the supernatant was strained through a filter (mesh size, $35 \mu \mathrm{m}$ ) to remove suspended dietary particles. Bacterial cells in the filtrate were centrifuged ( $5000 \mathrm{~g}, 5 \mathrm{~min}$ ) and the pellet was resuspended in $1 \times$ PBS $(130 \mathrm{mM} \mathrm{NaCl}, 10 \mathrm{mM}$ sodium phosphate buffer, $\mathrm{pH} 7 \cdot 2$ ). The resultant suspension was used for FCM analysis and sorting.

FCM analysis and cell sorting were performed with a Coulter Epics Elite ESP instrument (Beckman Coulter) equipped with an argon ion laser $(488 \mathrm{~nm}, 15 \mathrm{~mW})$. The instrument was used to measure forward-angle light scatter (FS; related to size) and side-angle light scatter (SS; related to shape). Iso Flow (Beckman Coulter) was used as sheath fluid. The nozzle diameter was $100 \mu \mathrm{m}$. Sheath and sample pressures were kept constant and an analytical rate of approximately 200 events $\mathrm{s}^{-1}$ was maintained by diluting rumen fluid sample. The data were collected as two-dimensional

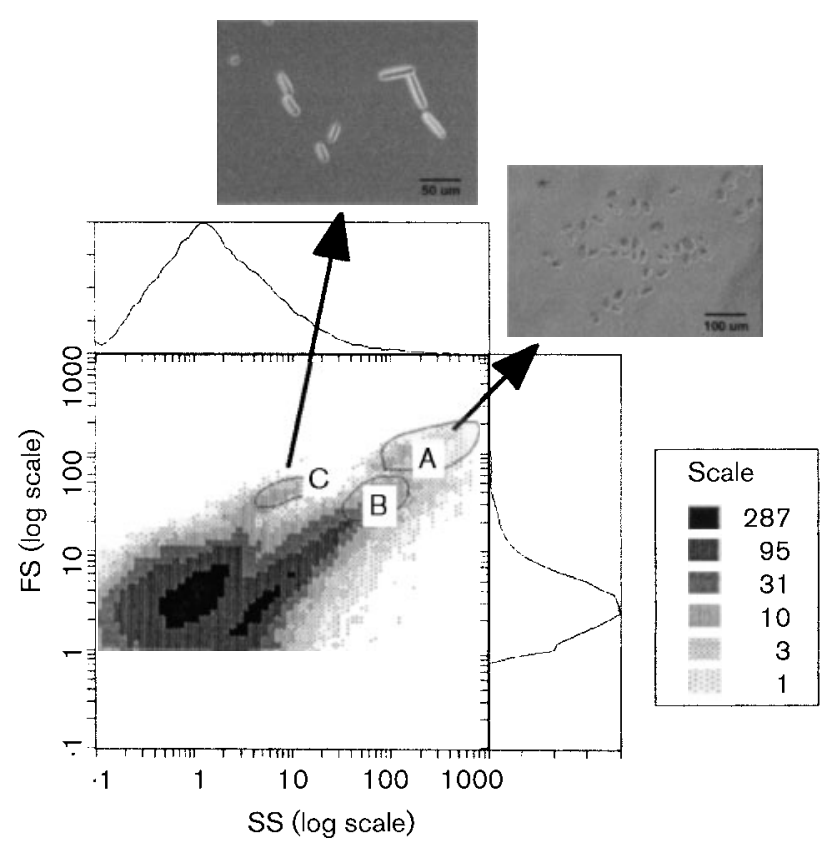

Fig. 1. FCM histogram of the sheep rumen sample. FCM cell sorting was performed by measuring forward-angle light scatter (FS) and side-angle light scatter (SS). The compositions of gates $A, B$ and $C$ are described in the text. histograms and analysis was done with the Coulter Epics Elite software (version 4.5).

The FCM histogram of the sheep rumen sample is shown in Fig. 1. FCM sorting resulted in three distinct fractions, indicated as gates A, B and C. Microscopic observation revealed that gate $\mathrm{A}$ contained a number of ciliate cells, gate B contained cell debris of ciliates and gate C contained Oscillospira cells. Transmission electron micrographs revealed that the cells in gate $\mathrm{C}$ showed a cross-wall structure or septum described previously as characteristic of O. guillermondii (Gibson, 1974; Grain \& Senaud, 1976) (Fig. 2). The Oscillospira cells accounted for over $95 \%$ of total cells in the gate $\mathrm{C}$ fraction. Based on the total organisms sorted, the Oscillospira cells accounted for less than $0 \cdot 4 \%$ of the total ciliate and bacterial cells in the rumen sample, an enrichment factor of greater than 230 . We again sorted the original rumen sample and approximately 5000 Oscillospira cells were collected for further $16 \mathrm{~S}$ rDNA cloning analysis and in situ hybridization experiments.

The PCR amplification mixture contained (per $50 \mu \mathrm{l}$ reaction): $1 \mu \mathrm{l}$ collected cells (approx. 100 Oscillospira cells), $1 \times$ Taq polymerase buffer, $2.5 \mathrm{U}$ Taq polymerase (Applied Biosystems), $10 \mu \mathrm{mol}$ dNTPs and 25 pmol of each primer. The PCR primer set for the PCR was the Eubacteria primer set Eub 10F (5'-AGAGTTTGATCCTGGCTCAG) and Eub 1500R (5'-GGTTACCTTGTTACGACTT) (Weisburg et al., 1991). The PCR amplification conditions were as

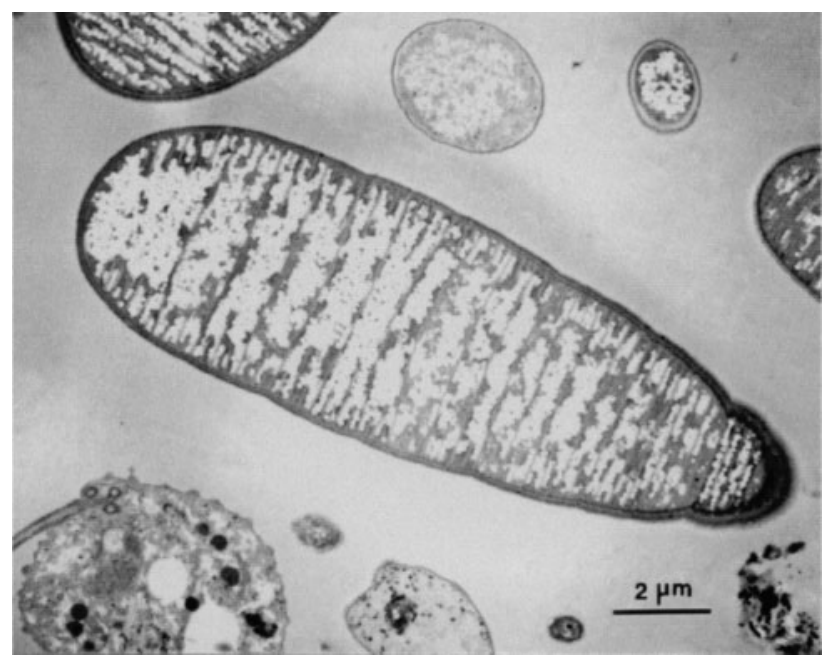

Fig. 2. Transmission electron micrograph of an FCM-sorted Oscillospira cell. Cells sorted through FCM were fixed with $2.5 \%(\mathrm{w} / \mathrm{v})$ glutaraldehyde overnight and then post-fixed in $1.5 \%(\mathrm{w} / \mathrm{v})$ osmium tetroxide at $4{ }^{\circ} \mathrm{C}$ for $3 \mathrm{~h}$. The fixed cells were stained with uranyl acetate for $1 \mathrm{~h}$ at room temperature, dehydrated and embedded in Spurr low-viscosity resin. Thinsections of the cells were cut with an ultramicrotome (Reichert Ultracut $\mathrm{N}$ ) and examined using a transmission electron microscope (Hitachi $\mathrm{H}-7000)$ operated at $75 \mathrm{kV}$. 
follows: denaturation and DNA extraction at $95^{\circ} \mathrm{C}$ for $9 \mathrm{~min}$, followed by 35 cycles of $95^{\circ} \mathrm{C}$ for $1 \mathrm{~min}, 50^{\circ} \mathrm{C}$ for $1 \mathrm{~min}$ and $72^{\circ} \mathrm{C}$ for $2 \mathrm{~min}$. PCR products were purified with a MicroSpin S-400 HR column (Pharmacia Biotech). Cloning of the PCR product was carried out by using pT7 blue T-vector (Novagen), a DNA ligation kit (Takara Shuzo) and Escherichia coli DH5 $\alpha$ (Toyobo). Cloned 16S rDNAs were prepared from randomly selected recombinants and used as templates for DNA sequencing. Sequencing was conducted with a DNA sequencer (model 377; Applied Biosystems) using sequencing primers as described previously (Hiraishi et al., 1994). The sequences were analysed with closely related sequences of reference organisms from the BLAST network service (Altschul et al., 1990) and Ribosomal Database Project 2 (RDP2) (Maidak et al., 1999). Sequence data were aligned with CLUSTAL W (Thompson et al., 1994). A phylogenetic tree was constructed by the neighbour-joining method (Saitou \& Nei, 1987) with the MEGA program package (Kumar et al., 1993). Bootstrap resampling analysis (Felsenstein, 1985) for 100 replicates was performed to estimate the confidence of the tree topologies.

Twenty randomly chosen clones were partially sequenced. Sequencing revealed that all of the cloned sequences formed one cluster and, therefore, five clones (OSC1, OSC2, OSC3, OSC4 and OSC5) were chosen for full sequencing and analysis. These sequences were found to have more than $97 \cdot 0 \%$ similarity to each other. Phylogenetic analysis indicated these sequences to be affiliated with the low$\mathrm{G}+\mathrm{C}$ subclass of the Gram-positive bacteria and to be distantly related to Sporobacter termitidis and Papillibacter cinnamivorans, with $86 \cdot 3-88 \cdot 1 \%$ sequence similarity (Fig. 3). S. termitidis is, as its name indicates, an anaerobic bacterium isolated from the paunch of the wood-feeding termite Nasutitremes lujae. S. termitidis is a chemoorganotroph that grows exclusively on a limited range of methoxylated aromatic compounds including 3,4,5trimethoxybenzoate and 3,4,5-cinnamate with ring cleavage and produces acetate as a major end product, suggesting that this bacterium may contribute, in part, to the degradation of lignocellulosic matter in the digestive tract of the termite (Grech-Mora et al., 1996). P. cinnamivorans is a strictly anaerobic bacterium that has been isolated from anaerobic digester sludge and is capable of metabolizing several methoxycinnamates (Defnoun et al., 2000).

Whether or not Oscillospira is capable of utilizing these substrates in the rumen ecosystem is unknown. To date, all attempts to grow the FCM-sorted Oscillospira cells anaerobically on various substrates have been unsuccessful. However, since Oscillospira was shown to be associated with the cuticular surface of clover and grass leaves in the rumen (Clarke, 1979), it is possible that they are involved in degradation of the plant cell wall. Indeed, the closest known ruminal species are Ruminococcus albus and Ruminococcus flavefaciens, prominent fibre-degrading bacteria (Stewart et al., 1997). The other notable finding was that the Oscillospira sequences are closely affiliated with cloned sequences within clostridial cluster IV obtained from the caecum of broiler chickens (GenBank accession no. AF376230) and the rumen content of a cow (Tajima et al., 2000), forming a coherent group with sequence similarities of $90 \cdot 2-91 \cdot 1 \%$. Interestingly, a cloned sequence from a human faecal sample also fell into this cluster (Suau et al., 1999), suggesting that micro-organisms within this cluster are widespread in the alimentary tracts not only of herbivores but also of omnivores.

Two Oscillospira-specific probes, S-G-Osci-621-a-A-19 (OSC 621) and S-G-Osci-808-a-A-20 (OSC 808), described using standardized nomenclature according to Alm et al. (1996), were designed using the BLAST network service (Altschul et al., 1990) and RDP2 (Maidak et al., 1999) for FISH (Table 1). The probes were labelled with FITC for in situ hybridization. FITC-labelled bacterial domain probe EUB 338 (Amann et al., 1990) and archaeal domain probe ARC 915 (Stahl \& Amann, 1991) were used as controls. Rumen fluid was fixed with $4 \%$ (w/v) paraformaldehyde/ PBS $(130 \mathrm{mM} \mathrm{NaCl}, 10 \mathrm{mM}$ sodium phosphate buffer, $\mathrm{pH} 7 \cdot 2$ ) for $3 \mathrm{~h}$ at $4{ }^{\circ} \mathrm{C}$, washed once with PBS and stored in PBS/ethanol $(1: 1, \mathrm{v} / \mathrm{v})$ at $-20^{\circ} \mathrm{C}$ until use. The fixed cells were spotted onto a slide (Bokusui Brown) and allowed to

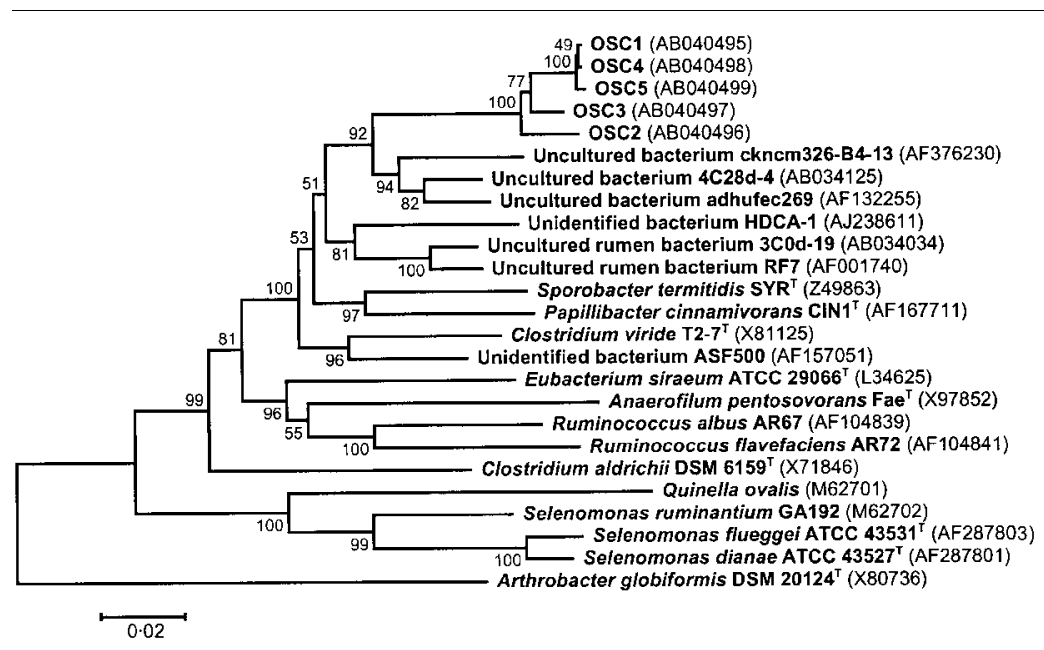

Fig. 3. Phylogenetic tree of cloned O. guillermondii 16S rDNA sequences OSC1, OSC2, OSC3, OSC4 and OSC5. The tree was constructed using the neighbour-joining method. Numbers at nodes show bootstrap values obtained from 100 resamplings. Bar, 0.02 substitutions per nucleotide. GenBank/DDBJ/ EMBL accession numbers are shown in parentheses. 
Table 1. 16S rRNA-targeted oligonucleotide probe sequences used in this study

Standardized probe names were derived according to the nomenclature of Alm et al. (1996).

\begin{tabular}{|lllll|}
\hline Probe & Standardized name & \multicolumn{1}{c|}{ Sequence $\left(\mathbf{5}^{\prime}-\mathbf{3}^{\prime}\right)$} & Specificity & Target site $(\boldsymbol{E}$. coli numbering) \\
\hline EUB 338 & S-D-Bact-0338-a-A-18 & GCTGCCTCCCGTAGGAGT & Bacteria & $338-355$ \\
ARC 915 & S-D-Arch-0915-a-A-20 & GTGCTCCCCCGCCAATTCCT & Archaea & $915-934$ \\
OSC 621 & S-G-Osci-621-a-A-19 & GACCCGCAGTTTCAAATGC & Oscillospira & $621-643$ \\
OSC 808 & S-G-Osci-808-a-A-20 & CCGCACACCTAGTATTGATC & Oscillospira & $808-831$ \\
\hline
\end{tabular}

air-dry (Amann et al., 1990). After dehydration in 50, 70 and $100 \%$ ethanol ( 3 min each), $10 \mu$ prewarmed hybridization buffer $(0.9 \mathrm{M} \mathrm{NaCl}, 20 \mathrm{mM}$ Tris/HCl, 0.01\% SDS, $20 \%$ formamide, $25 \mathrm{ng}$ probe) was spotted onto the fixed cells on the slide. The slide was incubated for $2 \mathrm{~h}$ at $46^{\circ} \mathrm{C}$ in a $50 \mathrm{ml}$ conical tube as an equilibrated chamber. After hybridization, the slide was washed with washing buffer $(318 \mathrm{mM}$ $\mathrm{NaCl}, 20 \mathrm{mM}$ Tris/ $\mathrm{HCl}, 0 \cdot 01 \%$ SDS) for $30 \mathrm{~min}$ at $48^{\circ} \mathrm{C}$. The slide was rinsed with distilled water, air-dried and mounted with Citifluor solution. Fluorescence was detected under an AX-80TR microscope (Olympus Optical) fitted for epifluorescence with a high-pressure mercury bulb and a fluorescence mirror unit for FITC. Hybridization signals were recorded with a C5810 colour chilled 3 CCD camera
(Hamamatsu Photonics) controlled by C5810 remote. Exposure times were 0.01 and $1 \mathrm{~s}$ for phase-contrast and epifluorescence microscopy, respectively.

Epifluorescence microscopy revealed that both probes hybridized specifically with Oscillospira cells in both the sorted fraction and the original rumen sample (Fig. 4). Bacterial domain probe EUB 338 hybridized with most of the bacterial cells, including Oscillospira cells, under the same conditions, whereas the archaeal domain probe ARC 915 did not hybridize with Oscillospira cells (data not shown).

Together with Oscillospira, Quinella ovalis and 'Magnoovum
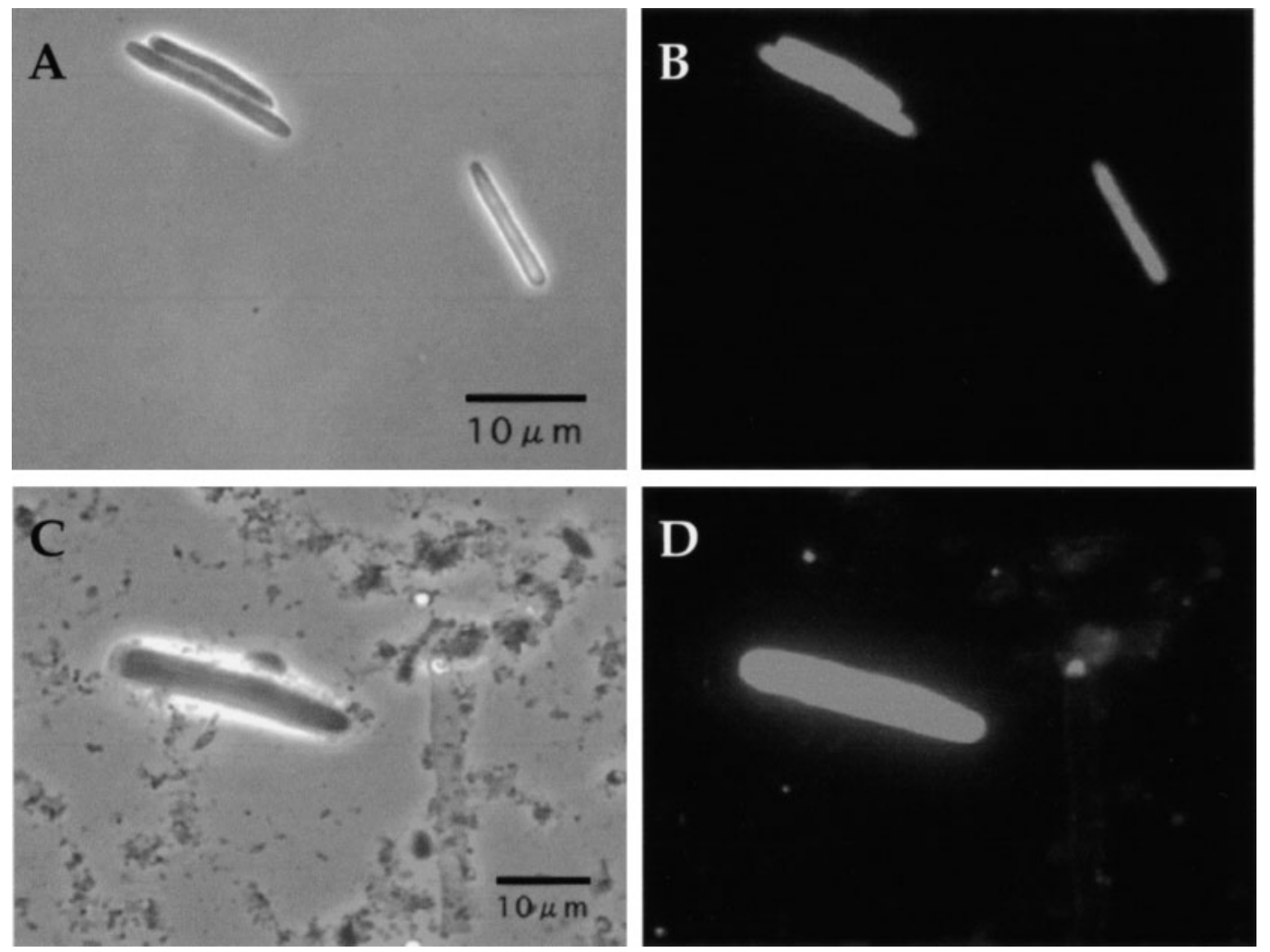

Fig. 4. FISH detection of Oscillospira cells using Oscillospira-specific probe OSC 621. Phase-contrast (A, C) and fluorescent $(B, D)$ micrographs of FCM-sorted Oscillospira cells (corresponding to the gate $C$ fraction in Fig. 1) (A, B) and the original rumen sample before sorting $(C, D)$. 
eadii' are also known as relatively large bacteria often seen in the rumen. The $16 \mathrm{~S} \mathrm{rDNA}$ sequence of $Q$. ovalis was determined and found to be affiliated with the SelenomonasMegasphaera-Sporomusa cluster (Krumholz et al., 1993). 'Magnoovum eadii' was characterized on the basis of cell wall analysis and biochemical tests (Orpin, 1976), although its phylogenetic position remains undetermined. Since pure cultures of these bacteria are not available, these studies were performed using enrichment culture or differential centrifugation to obtain cells. Considering the fact that a number of anaerobic protozoa and bacteria present in the rumen have not yet been cultured, molecular techniques such as FISH are powerful, culture-independent methods of monitoring their ecology. The FISH probes specific for Oscillospira designed and evaluated in this study could be used to evaluate changes in the population and morphology of this bacterium in relation to diet and other conditions.

In conclusion, FCM sorting and subsequent $16 \mathrm{~S}$ rDNA cloning, sequence analysis and probe design specific for Oscillospira were successful in determining the phylogenetic position of this morphologically distinct but uncultured ruminal bacterium.

\section{Acknowledgements}

This research was supported financially by the New Energy and Industrial Technology Development Organization (NEDO) and carried out in co-operative research with the Japan Bioindustry Association (JBA) and the National Institute of Advanced Industrial Science and Technology (AIST).

\section{References}

Alm, E. W., Oerther, D. B., Larsen, N., Stahl, D. A. \& Raskin, L. (1996). The oligonucleotide probe database. Appl Environ Microbiol 62, 3557-3559.

Altschul, S. F., Gish, W., Miller, W., Myers, E. W. \& Lipman, D. J. (1990). Basic local alignment search tool. J Mol Biol 215, 403-410.

Amann, R. I., Binder, B. J., Olson, R. J., Chisholm, S. W., Devereux, R. \& Stahl, D. A. (1990). Combination of $16 \mathrm{~S}$ rRNA-targeted oligonucleotide probes with flow cytometry for analyzing mixed microbial populations. Appl Environ Microbiol 56, 1919-1925.

Button, D. K., Robertson, B. R. \& Juettner, F. (1996). Microflora of a subalpine lake: bacterial populations, size, and DNA distributions and their dependence on phosphate. FEMS Microbiol Ecol 21, 87-101.

Chatton, E. \& Pérard, C. (1913). Schizophytes du caecum du cobaye. I. Oscillospira guillermondii n. g., n. sp. CR Soc Biol Paris 74, 1159-1162.

Clarke, R. T. J. (1979). Niche in pasture-fed ruminants for the large rumen bacteria Oscillospira, Lampropedia, and Quin's and Eadie's ovals. Appl Environ Microbiol 37, 654-657.

Davey, H. M. \& Kell, D. B. (1996). Flow cytometry and cell sorting of heterogeneous microbial population: the importance of single-cell analyses. Microbiol Rev 60, 641-696.

Defnoun, S., Labat, M., Ambrosio, M., Garcia, J.-L. \& Patel, B. K. C. (2000). Papillibacter cinnamivorans gen. nov., sp. nov., a cinnamatetransforming bacterium from a shea cake digester. Int J Syst Evol Microbiol 50, 1221-1228.
Felsenstein, J. (1985). Confidence limits of phylogenies: an approach using the bootstrap. Evolution 39, 783-791.

Gibson, T. (1974). Genus V. Sporosarcina Kluyver and van Neil 1936, 401. In Bergey's Manual of Determinative Bacteriology, 8th edn, pp. 573-574. Edited by R. E. Buchanan \& N. E. Gibbons. Baltimore: Williams \& Wilkins.

Gibson, T. (1986). Genus Oscillospira Chatton and Pérard 1913, $1159^{\mathrm{AL}}$. In Bergey's Manual of Systematic Bacteriology, vol. 2, p. 1207. Edited by P. H. A. Sneath, N. S. Mair, M. E. Sharpe \& J. G. Holt. Baltimore: Williams \& Wilkins.

Grain, J. \& Senaud, J. (1976). Oscillospira guillermondii, a rumen bacterium: ultrastructural study of the trichome and of sporulation. J Ultrastruct Res 55, 228-244 (in French).

Grech-Mora, I., Fardeau, M.-L., Patel, B. K. C., Ollivier, B., Rimbault, A., Prensier, G., Garcia, J.-L. \& Garnier-Sillam, E. (1996). Isolation and characterization of Sporobacter termitidis gen. nov., sp. nov., from the digestive tract of the wood-feeding termite Nasutitermes lujae. Int J Syst Bacteriol 46, 512-518.

Hiraishi, A., Shin, Y.-K., Ueda, Y. \& Sugiyama, J. (1994). Automated sequencing of PCR-amplified 16S rDNA on 'Hydrolink' gels. J Microbiol Methods 19, 145-154.

Jansson, J. K. \& Prosser, J. I. (1997). Quantification of the presence and activity of specific microorganisms in nature. Mol Biotechnol 7, 103-120.

Krumholz, L. R., Bryant, M. P., Brulla, W. J., Vicini, J. L., Clark, J. H. \& Stahl, D. A. (1993). Proposal of Quinella ovalis gen. nov., sp. nov., based on phylogenetic analysis. Int J Syst Bacteriol 43, 293-296.

Kumar, S., Tomura, K. \& Nei, M. (1993). MEGA: Molecular evolutionary genetics analysis, version 1.0. The Pennsylvania State University, University Park, USA.

Kurihara, Y., Eadie, J. M., Hobson, P. N. \& Mann, S. O. (1968). Relationship between bacteria and ciliate protozoa in the sheep rumen. J Gen Microbiol 51, 267-288.

Maidak, B. L., Cole, J. R., Parker, C. T., Jr \& 11 other authors (1999). A new version of the RDP (Ribosomal Database Project). Nucleic Acids Res 27, 171-173.

Orpin, C. G. (1976). The characterization of the rumen bacterium Eadie's oval, Magnoovum gen. nov. eadii sp. nov. Arch Microbiol 111, 155-159.

Saitou, N. \& Nei, M. (1987). The neighbor-joining method: a new method for reconstructing phylogenetic trees. Mol Biol Evol 4, 406-425.

Stahl, D. A. \& Amann, R. I. (1991). Development and application of nucleic acid probes in bacterial systematics. In Nucleic Acid Techniques in Bacterial Systematics, pp. 205-248. Edited by E. Stackebrandt \& M. Goodfellow. New York: Wiley.

Stewart, C. S., Flint, H. J. \& Bryant, M. P. (1997). The rumen bacteria. In The Rumen Microbial Ecology, 2nd edn, pp. 10-72. London \& New York: Blackie Academic \& Professional.

Suau, A., Bonnet, R., Sutren, M., Godon, J. J., Gibson, G. R., Collins, M. D. \& Dore, J. (1999). Direct analysis of genes encoding $16 \mathrm{~S}$ rRNA from complex communities reveals many novel molecular species within the human gut. Appl Environ Microbiol 65, 4799-4807.

Tajima, K., Arai, S., Ogata, K., Nagamine, T., Matsui, H., Namakura, M., Aminov, R. I. \& Benno, Y. (2000). Rumen bacterial community transition during adaptation to high-grain diet. Anaerobe 6, 273-284.

Thompson, J. D., Higgins, D. G. \& Gibson, T. J. (1994). CLUSTAL W: improving the sensitivity of progressive multiple sequence alignment through sequence weighting, position-specific gap penalties and weight matrix choice. Nucleic Acids Res 22, 4673-4680. 
Wallner, G., Fuchs, B., Spring, S., Beisker, W. \& Amann, R. (1997), Flow sorting of microorganisms for molecular analysis. Appl Environ Microbiol 63, 4223-4231.

Warner, A. C. I. (1966). Diurnal changes in the concentrations of micro-organisms in the rumens of sheep fed to appetite in pens or at pasture. J Gen Microbiol 45, 243-251.

Weisburg, W. G., Barns, S. M., Pelletier, D. A. \& Lane, D. J. (1991). $16 \mathrm{~S}$ ribosomal DNA amplification for phylogenetic study. J Bacteriol 173, 697-703.
Williams, A. G. \& Coleman, G. S. (1997). The rumen protozoa. In The Rumen Microbial Ecology, 2nd edn, pp. 73-139: London \& New York: Blackie Academic \& Professional.

Zoetendal, E. G., Ben-Amor, K., Harmsen, H. J. M., Schut, F., Akkermans, A. D. L. \& de Vos, W. M. (2002). Quantification of uncultured Ruminococcus obeum-like bacteria in human fecal samples by fluorescent in situ hybridization and flow cytometry using 16S rRNA-targeted probes. Appl Environ Microbiol 68, $4225-4232$. 